MARKETING AND BRANDING
RESEARCH $\begin{gathered}\text { INDUSTRIAL } \\ \text { MANAGEMENT } \\ \text { INSTITUTE }\end{gathered}$

\title{
The impact of relationship marketing on customer loyalty enhancement (Case study: Kerman Iran insurance company)
}

\author{
Abdolaziz Abtin ${ }^{1 *}$, Mostafa Pouramiri ${ }^{2}$ \\ ${ }^{1}$ Assistant Professor, Department of Management, Chabahar Maritime University \\ ${ }^{2}$ MSc Student in Information Technology Management, Department of Accounting and Management, \\ University of Sistan and Baluchestan
}

Keywords:

Customer Relation Management (CRM), Relationship Marketing, Electronic Communication

Correspondence: abtin@cmu.ac.ir

\begin{abstract}
Nowadays, only those trading that just focus on the effectiveness of the marketing mix elements can shift their direction towards relationship marketing and establishing effective relationship management with customers. In today's competitive world, customers are in the center of companies' attention and their satisfaction is the main factor in gaining competitive advantage. The fundamental prerequisite for achieving customers' satisfaction is to fully meet or exceed their needs, wants, desires, expectations, and their willingness to purchase products. To gain competitive advantage, the companies should pay more attention to customers' needs and meet them better than their rivals. This paper aims to investigate the impact of relationship marketing on customer loyalty enhancement in Kerman Iran insurance company. This study was carried out through a survey method using questionnaires as the main instrument. Pearson correlation coefficient was used to assess the relationship between loyalty as dependent variable and trust, satisfaction, management, communication, and competence as independent variables and revealed that there was a significant positive relationship between variables.
\end{abstract}

CAIMI Journals

\section{Introduction}

Today, mature markets which have reached to the equilibrium and have different properties in comparison to the past. Its main features are expertise, customer power, and advertisement impact reduction. Today, suppliers of industrial and consumer goods market face with 
customers who have unlimited demands but less are influenced by traditional marketing tools. On the other hand, there is no big difference between market goods from customers' perspective. If a customer does ask for a brand name which is not available, he can easily substitute other brands. This represents a decrease in customer loyalty. Price competition has lost its pervious meaning and market-oriented and customer-oriented organizations try to maintain and increase customer loyalty as a new marketing tool rather than competing on price (Christopher, 1996). Since the early 1980s, many companies establish sustainable relationships with suppliers and other beneficiaries and then in early 1983 the term "marketing" was introduced for the first time (Wang, 2007). This study was conducted to investigate the impact of relationship marketing on customer loyalty enhancement in Kerman Iran insurance company. It tries to investigate the impact of variables such as trust, satisfaction, management, communication, and competence on customer loyalty in Kerman Iran insurance company.

\section{Relationship Marketing}

The concept of relationship marketing was presented initially in 1983 by Berry in the context of service organizations. It is defined as a business strategy to attract, maintain, and improve customer relations with technology development (Berry, 1983) and companies are paying to create beneficial relationships based on to optimize customer perceptions value. Some others defined relationship marketing as a process to identify, build, maintain, strengthen, and if necessary terminate their mutually beneficial relationships with their customers and other stakeholders so that the objectives of all the parties involved are met (Gronroos, 1999). Kotler, Armstrong, Saunders, and Wong (1999) defined relationship marketing as an effort to create, maintain, and enhance strong relationships with target customers and stakeholders. They believe that marketing is increasingly moving away from individual transactions to build strong relationship with customers and other marketing networks.

\section{Customer Concept}

Customers are people who consume, need, or benefit from the product or the results of its function because each function in an organization certainly has a goal and its own customers (Bernickerhouf \& Dressler, 2003). Totally, customers can be divided into two distinct categories, namely internal and external customers. An external customer is someone who is not part of an organization and just purchases and uses the company's products or services. In addition to external customers, every organization has its own internal customers that are important as well as external customers. An internal customer is any member of organization who receives a product or service and instead offers a product or service in all stages of organizational or operative processes (Jafari \& Fahimi, 2000).

\section{Customer Satisfaction}

Relationship marketing is a long-term approach that its main objective is providing superior customer value over the long period of time and the primary success criterion is to develop long-term customer satisfaction (Kotler et al., 1999).Customer satisfaction is achieved through consumption and purchase experience (Sharma \& Patterson, 2000). Customer 
satisfaction can be considered as the final basis in the modern marketing; therefore, the success of each business institution depends heavily on identifying and satisfying the superior customers' needs and demands. Customer satisfaction can lead to behaviors such as loyalty and positive word of mouth advertising (Abdul-Mauhmin, 2002).

\section{Effect of Customer Satisfaction on Customer Loyalty}

Customer loyalty is considered as a key business strategy and greatest asset of each company that guarantees company's success and improves its level of profitability. In today's fastpaced world of constant change, creating and maintaining customer loyalty need more attempts. Electronic commerce is considered as a way to reduce entry barriers and provides an excellent opportunity for customers to see and select the proper supplier (seller). Most of old trade organizations did not consider to the new customer service techniques new and therefore lost their own existing customers. Moreover, organizations should not assume that customer loyalty management is equal to customer management for profitability. Loyal customers are considered as great marketers and valuable source for selling (Maghsoudi, 2003).

\section{Principles and Purposes of Relationship Marketing}

Relationship marketing therefore aims at improving company's profitability through changing company's view of trading marketing and emphasizing to attract new customers by applying effective customer relationship management. Relationship marketing attempts to involve customers, suppliers, and other key economic partners into company's development and marketing activities. Such involvements lead to the creation of close interactive relationships with suppliers, customers, and other value chain partners. An integrative relationship requires mutual overlap in plans and processes of both parties and recommends close economic, emotional, and structural bonds among them. It reflects the binary dependence rather than the independence among the parties and emphasize on cooperation rather than competition and conflict among market participants. Therefore, development of relationship marketing refers to the significant shift in marketing principles that is competition and conflict to mutual cooperation (Salari, 2004).

\section{Relationship Marketing and Relationship Management Applications}

The process of creating strong customer loyalty bonds is called relationship marketing. Three approaches have been proposed to develop a strong bond with customers. The first approach is to increase the financial benefits to the customers. However, these financial benefits could be imitated by competitors and therefore there will be no permanent distinction for the firm. The second approach is that in addition to the financial benefits to customers social benefits should also be provided for customers. It means that the individual needs and wants of customers are firstly recognized by the company and offered appropriate individualized services to them. Finally, the third approach states that structural links or relations should be added to the financial and social benefits (Salari, 2004). 


\section{New Concept of Customer Service}

The concept of customer service encompasses some new definitions that states that the entire organization consists of top managers and ordinary employees (not just a small part of it) specializes to offer services which meet the real needs of existing and potential customers. Even if a person is not in a position to directly support the customer, he can support employees who serve the customers. According to this view, customer service consists of all activities that a company does to satisfy its customers and helps them to get the most value out of the services they have purchased. This broad definition encompasses everything other than provision of the core services which offer to the customers and distinguish their services from their competitors' services (Venous \& Safaeian, 2005). Reichheld and Sasser (1990) presented some reasons that shows customer retention brings profitability for organizations. First, the cost of attracting new customers may be high; therefore, the customers will not be profitable unless they are preserved for a longer time and purchase from company. Second, the resulting optimal stream of profits earned from customer retention and loyalty will help the company to cover its costs. By increasing the purchase of most customers from company, the earnings will increase and the company will enjoy greater efficiency in providing services to consumers; therefore, the costs are reduced. Happy and faithful customers will attract more potential customers to the company. Customer relationships are valuable to companies and therefore loyal customers will be less price sensitive.

\section{Electronic Customer Relationship Management (ECRM)}

Philip Kotler (2002) considered electronic customer relationship management(ECRM)as a part of electronic business concept which defines the use of electronic tools for directing the companies' affairs and enables companies to provide proper, fast, precise, and affordable services for their customers on a wide range of temporal and special scales. ECRM can also increase the efficiency and effectiveness of the communications and make the goods and services customized and specialized. It can also be used as a tool to attract and retain economically valuable customers, remove or eliminate non-economic cases, combine software, hardware, processes for business, applications and management commitment, and building and maintaining customer relationships through e-business operations (Elahi \& Heidari, 2008).

\section{Integrated Customer Relationship Management (ICRM)}

To overcome the drawbacks of current CRM operations, the experts proposed the concept of integrated customer relationship management (ICRM). This concept provides the theoretical framework to define and establish communication with customers according to their needs in a purely competitive market. It also offers a standard practical process guide for effective customer relationship management. Integrated customer relationship management states that the companies by making strong connections with their customers can create sustainable competitive advantages in the long run.

Therefore, the primary goal of marketing activities is building a stronger relationship with customers in CRM, which requires that all of the marketing functions act to improve the communication with customers. ICRM integrates all major marketing functions in the process 
of building strong customer relationship and determines the type of relationship based on customers and companies' main needs. Therefore, needs determine the values and values determine the type of relationship with customers. To attract customers throughout the lifetime, only keeping track of them in the databases or recording their purchases in organization are not enough. A company must maintain its relationship with customers by providing the best value compared to its competitors. The key point in ICRM is the understanding of customer relationship under market competitions (Elahi \& Heidari, 2008).

\section{Factors Affecting Relationship Marketing}

According to Gronroos (1999) accepting relationship marketing creates a large number of changes in company's old structures and interactions; therefore, he introduced eight types of factors which affect the success of relationship marketing. These factors are marketing resources and variables, product, organizational structure, outsourcing, marketing planning, paying attention to individual customers, information resources, and communication attitude. Marketing resources and variables states that the companies are not able to predict the set of relationship marketing variables and therefore they should apply their resources to create a proper marketing based on their relationships with each of their customers, so that the results lead to the customers' satisfaction and give them value. Second, the companies never rely on prefabricated products in relationship marketing. They should expand their current resources such as their personnel and technology and make a system which presents services through optimal resource management to satisfy their customers. Third, marketing knowledge should not be just limited to a separate organizational unit in relationship marketing and needs to be shared and developed throughout the organization. Although, marketing experts are required to execute some traditional marketing functions such as advising to senior managers for making decision. Fourth, the implementation of relationship marketing in companies should be outsourced and should be done by part-time marketing experts. These marketing experts should ensure the companies that their marketing duties with customer-oriented tendency will be achieved. Fifth, planning in relationship marketing should move away from traditional marketing planning towards making customer relationships and understanding customers' circumstances. Furthermore, in relationship marketing, marketing decisions and activities should not be based on the traditional marketing segmentation methods but also on selecting customer and providing services for individual customers based on searching customers' database and data. Information sources also states that companies should acquire their information through face-to-face communication with their customers. For successful implementation of relationship marketing program in the organization, the concept of marketing should be replaced with other concepts such as cross-enterprise customer relationship management.

\section{Main Advantages of using CRM}

Customer relationship management (CRM) has some advantages such as ability to influence the customer profitability, providing integration program across the channel, improving the efficiency of sales team, personal marketing messages, customized products and services, 
improving effectiveness of customer services, and improved the prices (Richards \& Jones, 2008).

\section{Conceptual Model}

Previous studies clearly indicated that various factors affected on the customer loyalty. Considering this, several models and structures of these factors have been studied. An overview of this study is presented in the conceptual framework which is given in Figure 1.

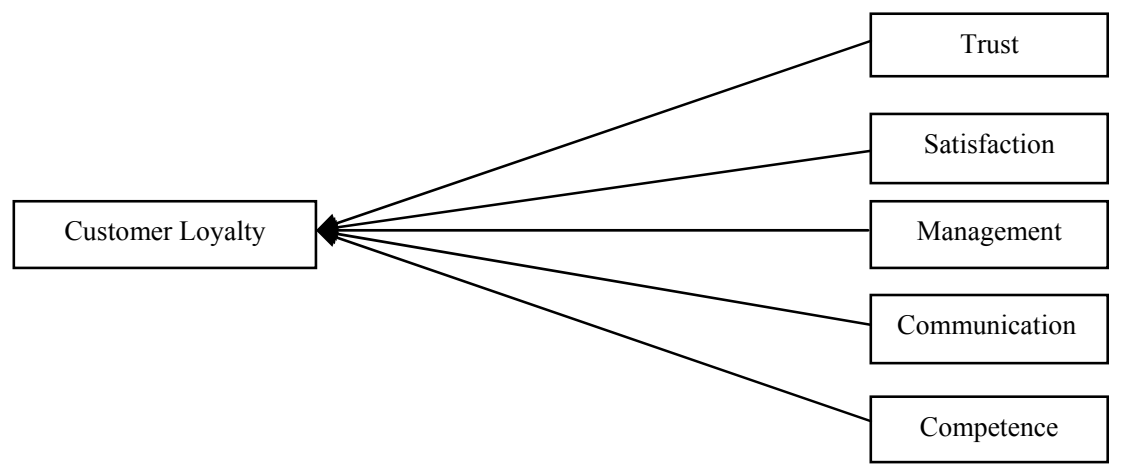

Figure 1. The conceptual Framework of study

\section{Research Hypotheses}

The main hypotheses of the current study were as follows:

$\mathbf{H}_{1}$. Trust has a significant impact on the customer loyalty in Kerman Iran insurance company.

$\mathbf{H}_{2}$. Satisfaction has a significant impact on the customer loyalty in Kerman Iran insurance company.

$\mathbf{H}_{3}$. Management has a significant impact on the customer loyalty in Kerman Iran insurance company.

H. Communication has a significant impact on the customer loyalty in Kerman Iran insurance company.

H. Competence has a significant impact on the customer loyalty in Kerman Iran insurance company.

\section{Procedure}

The statistical population of this study consisted of 155 customers of insurance services visited the central branch of Kerman Iran insurance company which were selected by simple random sampling. The average age of the customers was 37 with an age range of 20 to 55 years. In order to collect data and to test the hypotheses of the study, a questionnaire was developed and distributed among 180 customers of central branch of Kerman Iran insurance company. After the elimination of incomplete questionnaires, 155 valid questionnaires were used for analysis in this study. To confirm the validity of the questionnaire, the researcher asked two experts in the field to rate the instrument's efficiency in terms of how effectively it measures participants' loyalty. Participants were instructed to rate themselves using a five point Likert Scale where 1 represents "strongly agree" and 5 "strongly disagree". Based on the data gathered, the reliability coefficient of questionnaire was calculated through 
Cronbach's alpha to be 0.86 . Therefore, the reliability and validity of the questionnaire were confirmed.

\section{Results}

The research hypotheses were tested using the descriptive and inferential statistical methods. Table 1 presents the distribution of the participants of the study according to their demographic information.

Table 1

Descriptive Statistics of Respondents

\begin{tabular}{|c|c|c|c|}
\hline Variable & & Frequency & Frequency Percentage \\
\hline \multirow{4}{*}{ Age } & $20-30$ & 28 & $17.9 \%$ \\
\hline & $31-40$ & 45 & $28.8 \%$ \\
\hline & $41-50$ & 53 & $34 \%$ \\
\hline & 51 and higher & 30 & $19.2 \%$ \\
\hline \multicolumn{4}{|l|}{ Gender } \\
\hline & Male & 110 & $71 \%$ \\
\hline & Female & 45 & $29 \%$ \\
\hline \multirow{5}{*}{ Education } & Diploma and Lower & 36 & $23.1 \%$ \\
\hline & Associate of Arts & 58 & $37.2 \%$ \\
\hline & Bachelor & 50 & $32.1 \%$ \\
\hline & Master & 9 & $5.8 \%$ \\
\hline & Ph.D. & 3 & $1.9 \%$ \\
\hline \multirow{5}{*}{$\begin{array}{l}\text { Number of Customers Visiting the } \\
\text { Central Branch of Kerman Iran } \\
\text { Insurance Company }\end{array}$} & First Visiting & 63 & $40.6 \%$ \\
\hline & Second Visiting & 53 & $34.2 \%$ \\
\hline & Third Visiting & 31 & $20 \%$ \\
\hline & Fourth Visiting & 2 & $1.3 \%$ \\
\hline & Fifth and More Visiting & 6 & $3.9 \%$ \\
\hline
\end{tabular}

The relationship between customer loyalty and each various factors affected on it including trust, satisfaction, management, communication, and competence was investigated using Pearson correlation coefficient. Preliminary analyses were performed to ensure no violation of the assumptions of normality, linearity, and homoscedasticity. The results revealed that there were strong positive correlations between dependent variable (customer loyalty) and each of independent variables including trust, satisfaction, management, communication, and competence $(p<0.05)$. The relationship between each independent variables and customer loyalty was direct. It means that as each of independent variables, namely trust, satisfaction, management, communication, and competence increased, customer loyalty also increased as well. The results of running Pearson correlation test and testing hypotheses are presented in Table 2.

Table 2

Pearson's Correlation Coefficient between Variables of Model

\begin{tabular}{lccccc}
\hline Variables & Loyalty & Trust & Satisfaction & Management & Communication \\
\hline Loyalty & 1 & & & & \\
Trust & $0.70^{* *}$ & 1 & & & \\
Satisfaction & $0.72^{* *}$ & $0.73^{* *}$ & 1 & 1 & 1 \\
Management & $0.46^{* *}$ & $0.40^{* *}$ & $0.57^{* *}$ & $0.42^{* *}$ & $0.56^{* *}$ \\
Communication & $0.62^{* *}$ & $0.61^{* *}$ & $0.66^{* *}$ & & $0.54^{* *}$ \\
Competence & $0.61^{* *}$ & 0.64 & $0.68^{* *}$ & & \\
\hline$* * P<0.01(2-a i l e d)$ & & & & &
\end{tabular}




\section{Discussion and Conclusion}

The present study is being constructed to realize the intensity and impact of relationship marketing practices adopted by central branch of Kerman Iran insurance company over the customer loyalty. In recent years, marketers have focused their attention on relationship marketing as a tool for customer loyalty. Therefore, the success of relationship marketing strategy depends on the benefits sought by individual retailer. The positive effects of factors such as trust, satisfaction, management, communication, and competence on increasing customer loyalty were considered in this study. Results indicated a statistically significant relationship between customer loyalty and each of independent variables consist of trust, satisfaction, management, communication, and competence. The results of this study support the findings of several previous studies such as Kahraman and Ndubisi (2005) and Fry et al. (1973). Cottrell (1995) argued that trust is essential for customer loyalty where trust indicate the product quality. Based on the result of this research, respondents were clearly keen about product quality to convert from ordinary customer to loyal customer. The findings also were not congruent with Reynolds and Arnold (2000) who stated that emotional loyalty is not developed by loyalty points and reward.

It gives the managers and employees of companies a broader perspective and ability to create a positive atmosphere to increase their costumers' loyalty. They should consider that customers clearly want qualified products with fair prices in the competitive market in order to meet their satisfaction and expectations. Further studies should research the impact of relationship marketing on customer loyalty enhancement in different populations and in different contexts. Moreover, examining the common concepts of relationship marketing and customer relationship management revealed that the successful companies should apply relationship-marketing strategies as competitive advantage to retain their existing customers through long-term and stable relations and seeking feedback to improve their customers' satisfaction and loyalty.

\section{References}

Abdul-Mauhmin, A. G. (2002). Effects of suppliers marketing program variables on industrial buyer relationship satisfaction and commitment. Journal of Business \& Industrial Marketing, 17(7), 637-651.

Berry, L. L. (1983). Relationship marketing. In L. L. Berry, G. L. Shostack, and G. D. Upah (Eds.), Perspectives on services marketing (pp. 25-28). Chicago: American Marketing Association.

Bernickerhouf, R., \& Dressler, D. (2003). Measuring productivity: A guide for managers and specialists (M. Abdollahzade, Trans.). Tehran: Cultural Research Bureau Publication.

Christopher, M. (1996). From brand values to customer value. Journal of Marketing Practice: Applied Marketing Science, 2(1), 55-66.

Cottrell, R. J. (1995). Proactive relationship management: The next step to long term customer loyalty. Customer Satisfaction Result, 25, 19-41.

Elahi, S., \& Heidari, B. (2008). Client relationship management. Tehran: Commercial Publishing \& Printing Company.

Fry, J. N., David, C., Shaw, C., Lanzenauer, H. V. C., \& Dipchand, C. R. (1973). Customer loyalty to banks: A longitudinal study. Journal of Business, 46(4), 517-525.

Grönroos, C. (1999). From marketing mix to relationship marketing: Towards a paradigm shift in marketing. Management Decision, 32(2), 329-334.

Jafari, M., \& Fahimi, A. (2000). Strategic and cultural tools and management of comprehensive quality. Tehran: Rasa Cultural Institute Publication. 
Kahraman, C., \& Ndubisi, N. O. (2005). Malaysian women entrepreneurs: Understanding the ICT usage behaviors and drivers. Journal of Enterprise Information Management, 18(6), 23-35.

Kotler, P., Armstrong, G., Saunders, J., \& Wong, V. (1999). Principles of marketing. New Jersey: Prentice-Hall, Upper Saddle River.

Kotler, P. (2002). When to use CRM and when to forget it! Paper presented at the Academy of Marketing Science, Sanibel Harbour Resort and Spa.

Maghsoudi, M. H. (2003). The relationship between customer satisfaction with the efficiency and effectiveness of processes. Proceedings of the Fourth Conference of Quality Management, Iran.

Reichheld, F. F., \& Sasser, W. E. Jr. (1990). Zero defections: Quality comes to services. Harvard Business Review, 68(5), $105-111$.

Reynolds, K. E., \& Arnold, M. (2000). Customer loyalty to the salesperson and the store: Examining relationship customers in an upscale retail context. Journal of Personal Selling \& Sales Management, 20 (2), 89-98.

Richards, A., \& Jones, E. (2008). Customer relationship management: Finding value drivers. Industrial marketing management, 37, 120-130.

Salari, G. (2004). Relationship marketing. Tadbir Journal, 148, 46-48.

Sharma, Neeru., \& Patterson, P. G. (2000). Switching costs, alternative attractiveness and experience as moderators of relationship commitment in professional, consumer services. International Journal of Service Industry Management, 11(5), 470-490.

Venous, D., \& Safaeian, M. (2005). Applicable methods of marketing in banking services for Iranian banks (4 ${ }^{\text {th }}$ ed.). Tehran: Negah-e Danesh Publications.

Wang, C. L. (2007). Guanxi vs. relationship marketing: Exploring underlying differences. Journal of Industrial Marketing Management, 36(1), 81-86. 